\title{
KAJIAN SEMANTIK KATA 'DAMAI SEJAHTERA’ DALAM BAHASA INDONESIA
}

\author{
Hendarto Supatra \\ Fakultas Ilmu Budaya Universitas Diponegoro Semarang \\ anton.bowo.w@gmail.com
}

\begin{abstract}
There is no expression Damai Sejahtera in Kamus Besar Bahasa Indonesia. In this dictionary we can find the meaning of damai and the meaning of sejahtera. That proves that DS is not a word but a phrase. In fact DS is not difference with damai dan sejahtera. The phrase that found in the Bible (John 14, verse 27) and commonly used among Indonesian Christians get its equivalent peace in English Bible and tentrem rahayu in Javanese Bible. Peace that commonly translated damai in Indonesian si not true in Indonesian Bible. Damai Sejahtera discussed in this article got its original concept from ancient Christian society not from English. That must be the reason. Budhism use the word bahagia meaning spiritual bliss with a special meaning which is not exactly the same with that that is used among Christian. So beside its common meaning used and known by all Indonesian people, speakers of bahasa Indonesia, DS also has specific meanings among Indonesian subculture like Budhis community, Muslim community, Christian community, etc.
\end{abstract}

Keywords: makna konseptual, makna konotatif, makna dasar, makna subkultural.

\section{Intisari}

Tidak ada ekspresi Damai Sejahtera (DS) dalam Kamus Besar Bahasa Indonesia. Dalam kamus ini kita bisa menemukan makna damai dan makna sejahtera. Itu membuktikan bahwa DS bukan kata tapi sebuah ungkapan. Padahal DS tidak beda dengan damai dan sejahtera. Ungkapan yang ditemukan di dalam Alkitab (Yohanes 14, ayat 27) dan yang umum digunakan di kalangan orang Kristen Indonesia mendapatkan kedamaian yang setara dalam Alkitab Inggris dan tentrem rahayu dalam Alkitab Jawa. Perdamaian yang biasa diterjemahkan dalam bahasa Indonesia tidak benar dalam Alkitab Indonesia. Damai Sejahtera yang dibahas dalam artikel ini mendapat konsep awalnya dari masyarakat Kristen kuno bukan dari bahasa Inggris. Itu pasti alasannya. Budisme menggunakan kata bahagia yang berarti kebahagiaan spiritual dengan makna khusus yang tidak persis sama dengan yang digunakan kalangan Kristen. Jadi selain arti umum yang digunakan dan dikenal oleh seluruh masyarakat Indonesia, penutur bahasa Indonesia, DS juga memiliki makna spesifik di antara subkultur Indonesia seperti komunitas Budhis, komunitas Muslim, komunitas Kristen, dan lain lain.

Kata kunci: makna konseptual, makna konotatif, makna dasar, makna subkultural. 


\section{Pendahuluan}

Sebuah kata atau frasa merupakan tanda ( sign) yang bermakna karena merujuk kepada realitas yang ada di luar tanda itu sendiri atau di luar bahasa. Tanda bisa berwujud artefak, segala sesuatu yang bersifat fisik, yang dapat diindra, atau berupa tindakan. Demikianlah ciri tanda, yakni selalu merujuk ke sesuatu yang lain yang lebih penting dan berupa sesuatu yang tertangkap oleh indra, atau menurut istilah Zoest (1993: 11-13) “...dapat diamati dan ... merujuk ke sesuatu yang tidak hadir" (Lihat juga Fiske 1982: 44). Demikian pula dengan bentuk damai sejahtera. Yang dimaksud dengan bentuk di sini adalah tanda (bahasa) yang bisa berupa morfem, Kata, Frasa, Kalimat, atau pun teks. Adapun istilah lain untuk bentuk adalah ekspresi. Apakah makna atau arti dari ekspresi damai sejahtera itu, itulah yang menjadi tujuan penelitian ini. Akan tetapi mengapa mesti damai sejahtera? Sebenarnya setiap bentuk atau ekspresi bisa menjadi objek kajian semantik yang hasilnya antara lain sangat bermanfaat untuk pengembangan kamus yang sudah ada. Adapun alasan khususnya adalah sebagai berikut.

Yohanes, salah seorang penulis Injil (dalam Alkitab Terjemahan Baru,2008) melaporkan bahwa suatu saat Gusti Yesus pernah bertutur sebagai berikut : "Damai sejahtera kutinggalkan bagimu. Damai sejahtera-Ku Kuberikan kepadamu, dan apa yang Kuberikan tidak seperti yang diberikan oleh dunia kepadamu. Janganlah gelisah dan gentar hatimu" (pasal 14: 27).

Jangankan mereka yang bukan orang Kristen, kebanyakan orang Kristen pun akan mendapatkan kesulitan untuk menangkap makna damai sejahtera yang ada dalam ayat tersebut di atas. Damai sejahtera dalam konteks ayat tersebut di atas merupakan damai sejahtera dalam pengertian khusus yakni bukan damai sejahtera yang dimaksudkan secara umum yakni damai sejahtera yang diberikan oleh dunia ini seperti misalnya karena merasa berharta, berkekuasaan, ternar, dsb. Lalu, seperti apakah damai sejahtara yang dimaksud itu? Hal itu menjadi lebih menantang untuk diselidiki secara lebih mendalam ketika ekspresi tersebut ternyata bersinonim dengan sejahtera (Alkitab dalam bahasa Indonesia Sehari-hari 1992: 2003),dengan selamat (Kitab Injil, Toehan Kita Yesoes Kristoes, Tersalin kepada bahasa Melayoe Rendah, 1934:236). Adapun dalam Alkitab berbahasa Jawa damai sejahtera (DS) berpadanan dengan ekspresi tentrem rahayu (1981: 149). Akhirnya dalam bahasa Inggris DS dipadankan dengan kata peace (Holy Bible, New International Vertion, 2008: 263).

Jadi rupanya DS merupakan bentuk panjangnya dari kata sejahtara. Sejahtera yang mengandung komponen makna 'damai'. Atau, bisa juga dikatakan bahwa DS sama dengan damai yang mengandung komponen makna 'sejahtera', dan itu sama artinya dengan 'selamat'? Agaknya bentuk salam sejahtera yang diucapkan sebagai padanan Asyalam mukalaikum ... itu berasal dari DS yang khas kristiani itu. Rasanya tidaklah berlebihan ketika orang berspikulasi bahwa makna DS tidaklah jauh berbeda antara yang digunakan oleh umat Kristen dan umat Islam dikerenakan persinggungan historis kedua agama tersebut yang demikian nyata. Lalu apakah DS ini mempunyai makna yang lain di dalam agama Budha misalnya? 
Tulisan ini sudah tentu tidak akan langsung membahas makna DS baik dalam pengertian umum atau pun dalam pengertian khusus, sebagai sosiolek keagamaan, melainkan akan dibicarakan pula, bahkan lebih dahulu, aspek bentuk dan perilakunya dalam tataran sintaksis bahasa Indonesia.

\section{Bentuk dan Perilaku DM}

Dalam Kamus Besar Bahasa Indonesia (2011) tidak terdapat bentuk damai sejahtera, yang ada adalah kata damai dan kata sejahtera. Jadi DM merupakan hasil dari peristiwa penggabungan kata damai dan kata sejahtera. Oleh karena damai termasuk ke dalam kategori nomina sedangkan sejahtera termasuk ke dalam kategori adjektiva, maka hasil penggabungan itu berupa frasa nomina tipe endosentrik atributif. Namun simpulan tersebut yakni bahwa DM adalah frasa indosentrik masih harus dikatakan bersifat tentatif sebab kata damai juga bisa dibuktikan sebagai yang termasuk kategori adjektiv sebagaimana akan jelas dari data yang akan diketengahkan nanti.

Kata damai terdiri dari sebuah morfem atau merupakan bentuk monomorfemik dan merupakan morfem bebas. Berikut ini beberapa contoh yang didapatkan dari KBBI.

1. Di masa damai perindustrian maju pesat.

2. Penduduk kampung itu selalu hidup dengan damai.

3. semuanya dapat diselesaikan secara damai.

Kata damai dalam konteks tertentu terbukti berkategori adjektiva. Sehingga kata ini bisa dikatakan berkeanggotaan ganda atau bisa mengalami proses modifikasi zero. Berikut ini contoh kata damai yang termasuk ke dalam kategori adjektiva yang juga diambil dari KBBI.

4. Betapa damai hati kami.

Bandingkanlah data (4) di atas dengan data berikut ini.

5. Ke mana-mana kami pergi untuk mencari damai.

6. Ya. Damailah yang kami cari.

Berdasarkan data diatas terbukti bahwa kata damai sebenarnya adalah kata adjektiva yang bisa berubah kategorinya menjadi nomina tanpa dengan mengalami perubahan bentuk (zero modifikasi). Di samping proses morfologis jenis zero tersebut, didapatkan pula proses morfologis yang lain seperti proses afiksasi dan proses duplikasi, sehingga membentuk deretan paradikmatis sbb.

Damai

berdamai 


$$
\begin{aligned}
& \text { mendamaikan } \\
& \text { memperdamaikan } \\
& \text { pendamaian } \\
& \text { perdamaian } \\
& \text { kedamaian } \\
& \text { didamaikan } \\
& \text { terdamaikan } \\
& \text { pendamai }
\end{aligned}
$$

Kata-kata dengan bentuk dasar damai itu berelasi satu dengan yang lain secara paradigmatic atau asosiatif.

Kata mendamaikan dengan memperdamaikan tampak seolah merupakan sinonim sempurna. Tentu saja tidak demikian. Sinonim secara sempurna kalau benar terjadi biasanya tidak akan bertahan lama, mereka itu akan segera berbagi makna atau salah satunya akan menghilang. Mendamaikan berbeda dengan memperdamaikan dalam level konotatifnya. Yang satu terasa lebih formal dibandingkan dengan yang lain. Tidak terdapat bentuk *mendamai, *mendamaii, *didamai, *didamaii, *terdamai, dsb. Bentuk-bentuk itu merupakan bagian dari system bahasa Indonesia, artinya tidak menyalahi norma ketatabahasaan bI. Bisa dikatakan untuk sementara menjadi bentuk-bentuk tidur yang mungkin suatu saat digunakan. Bentukbentuk ini masih akan dibahas lebih lanjut nanti dalam pembahasan sisi kemaknaannya.

Kata damai bisa mengalami proses reduplikasi menjadi damai-damai dan damaidamaian, sedamai-damainya, misalnya saja dalam contoh berikut.

7. Sampai saat ini tampak damai-damai saja mereka itu.

8. Yang terjadi setahuku hanyalah damai-damaian.

9. Wujudkan damai sedamai-damainya. Pokonya selesailah masalah itu.

Bentuk sejahtera termasuk ke dalam kategori adjektiva. Dalam tataran morfologis kata tersebut bisa diturunkan menjadi menyejahterakan, penyejahteraan, dan kesejahteraan. Dari sini bentuk-bentuk tersebut membentuk deretan paradigmatic seperti berikut.

Sejahtera

menyejahterakan

disejehterakan

penyejahteraan 


\section{kesejahteraan}

Dari deretan paradigmatic di atas, terdapat bentuk-bentuk tidur seperti *bersejahtera, *menyejahtera, *menyejahterai, ?penyejahtera, dan *persejahteraan. Berikut contoh dalam kalimat.

10. Pemerintah wajib menyejahterakan rakyatnya.

11. Orang-orang disable seyogyanya disejahterakan oleh masyarakat.

12. Penyejahteraan itu dengan sendirinya terwujud ketika makmur dan adil itu menjadi kenyataan.

13. Demi kesejahteraan kita bersama ....

Sehubungan dengan katasejahtera ini dapat juga diturunkan bentuk ulang atau reduplikasi seperti sejahtera-sejahtera, sejahtera-sejahteraan, sesejahtera-sejehteranya. Berikut contoh dalam kalimat.

14. Pasca penganiayaan itu orang-rang Koptik tampak sejahtera-sejahtera saja.

15. Tentu itu bukan sejahtera-sejahteraan, sebab mereka memang beriman.

16. Jadi, sejahtera dalam arti sesejahtara-sesejahteranya.

Bentuk damai sejahtera dapat diinterupsi dengan kata dan sehingga menjadi damai dan sejahtera. Hal itu membuktikan bahwa damai sejahtera itu merupakan frasa bukan kata mejemuk. Sebagai frasa jenis indosentrik apositif mungkin sekali mengalami proses morfologis menjadi, misalnya, mendamaisejahterakan, didamaisejahterakan, dan kedamaisejahteraan.

Baik kata damai, sejahtera, maupun damai sejahtera dalam tataran sintaksis bisa menjadi pengisi slot subjek maupun predikat bahkan sebagai pengisi fungsi keterangan dalam wujut frasa eksosentrik. Berikut contoh-contoh dalam kalimat.

17. Damai sejahtera Kuberikan kepadamu. Damai sejahtera-Ku Kuberikan Kepadamu.

18. Kami semuanya damai sejahtera sebab kami iklas dan legawa.

Dalam data (17) terbukti bahwa sebagai nomina DS bisa berkedudukan sebagai subjek sedangkan dalam data (18) DS yang sekategori dengan iklas dan legawa menunjukkan kategorinya sebagai adjektiva. Sebagai adjektiva DS bisa mengisi fungsi keterangan yang tentu lalu membentuk frasa adverbial seperti contoh berikut.

19. Akhirnya demi imannya, Abraham meninggalkan kampong halamannya dengan damai sejahtera. 


\section{Makna Damai Sejahtera}

Di atas telah diterangkan bahwa DS merupakan padanan kata peace (inggris) dan tentrem rahayu (Jawa). DS dalam bahasa Melayu Rendah atau tepatnya dalam Alkitab terjemahan tahun 1934 dalam bahasa Melayu Semarang (Melayu Tionghua) berpadan dengan kata selamat. Akhirnya, dalam bahasa Indonesia ragam dasar ( bI sehari-hari) atau tepatnya dalam Alkitab berbahasa Indonesia ragam sehari-hari DS diterjemahkan menjadi sejahtera saja.

DS, damai sejahtera yang sebenarnya merupakan bentuk singkat dari frasa damai dan sejahtera itu secara semantic mengandung makna gabungan dari makna kedua kata tersebut. Dan hal itu merupakan upaya terakhir (paling kini) yang dilakukan untuk menerjemahkan kata dalam bahasa Yunani Koine yang terdapat antara lain dalam Injil Yohanes pasal 14, ayat 27, yang dalam alkitab Inggris ( Holy Bible, New International Version ) yakni peace.

Dalam Kamus Besar Bahasa Indonesia ( KBBI, 2011) halaman 290, kata damai diartikan 1) "tidak ada perang; tidak ada kerusuhan; aman", 2) "tentram; tenang", 3) "keadaan tidak bermusuhan". Adapun kata sejahtera dalam KBBI (hal. 1241) diartikan sebagai "aman sentosa dan makmur; selamat ( terlepas dari segala macam gangguan)". Makna (1) dan (3) kata damai merujuk pada perkara di luar atau dalam hubungannya dengan hal yang bersifat interpersonal. Sedangkan makna (2) yakni "tentram; tenang" merujuk pada suasana batin atau situasi internal orang. Paralel dengan kata damai, kata sejahtera juga merujuk ke keadaan di luar yakni "aman sentosa dan makmur" dan yang lain merujuk ke keadaan batin yakni "selamat" atau "terlepas dari segala macam gangguan". Demikianlah, damai sejahtera itu mempunyai rujukan baik ke keadaan di luar sana maupun keadaan batin orang perorang. Memang benar bahwa damai, tentram, selamat, dan sejahtera yang dialami orang perorang erat kaitannya dengan situasi dan kondisi di luar. Miskipun hilangnya DS juga bisa disebabkan oleh keadaan lain selain keadaan perang atau pun rusuh atau kekacauan politik, kegoncangan ekonomi, dsb.

Di samping makna umum, makna yang bisa diterima oleh segenap penutur bI, terdapat makna khusus, yang dalam kaitannya dengan DS ini, tentunya makna sosiolek keagamaan/ideology keagamaan. Tentu saja di samping sosiolek keagamaan atau ideology masih terdapat sosiolek yang lain seperti umur, gender, etnis, pendidikan, kelas social, dan kasta (Bandingkan Oetama, 1987; Holmes, 2001). Kalau toh di sini sengaja hanya dibicarakan dalam sosiolek keagamaan dikarenakan DS diperkirakan berkolokasi dengan kosakatakosakata yang menjadi cirri sosiolek keagamaan. Kata-kata yang dimaksud misalnya, iman, pengharapan, kasih, belas kasihan, sabar, pemaaf, ibadah, puji-pujian, puasa, zakat, solat, alkitab, toleran, nondiskriminasi, jihad, radikal, moderat, meditasi, samadi, dsb. DS bersinonim dengan kata bahagia, gembira dan, sukacita di samping kata selamat, dan sejahtera. Dibandingkan dengan kata bergembira dan sukacita yang lebih banyak berkaitan dengan perkara duniawi, kata bahagia lebih dekat dengan DS. Di dalam tradisi Budha misalnya, lebih sering digunakan kata bahagia daripada DS, dan dua kata ini berbeda satu dengan yang lain; kata bahagia bisa digunakan dalam kaitannya dengan hal-hal duniawi maupun rohani 
sedangkan DS cenderung ke perkara spiritual atau rohani. Baik senang, sukacita maupun gembira cenderung digunakan dalam kaitannya dengan yang sifatnya sesaat dan duniawi atau jasmaniah. Sedangkan damai sejahtera, sejahtera, dan selamat berkaitan dengan yang rohaniah atau spiritual. Gambarannya barangkali akan seperti berikut.

$$
\text { Senang ------ gembira ------ suka cita ------ damai sejahtera ------ selamat }
$$

Di samping makna atau konsep umum terdapat konsep atau konsep-konsep spesifik atau lebih tepatnya konsep masyarakat subbudaya Indonesia sebagaimana telah disinggung di atas, yakni sosiolek agama/ideology ( Bandingkan Durranti. 1997: 31 ). Sejumlah sahabat Muslim memberikan kesaksian perihal apa yang dialami sebagai pelaku setia agama yang dipeluknya yakni Islam. Mereka berkata bahwa Islam bagi mereka yang bersungguh-sungguh akan mendatangkan sejahtera dalam hidupnya. Kedamaian dan kesejahteraan dicapai ketika orang taat dan secara konsekuen melaksanakan solat, puasa, zakat, dan suatu saat berhaji. Damai sejahtera milik mereka yang tagwa. Beribadah itulah bukti ketagwaan yang berujung, antara lain, ke kedamaian.

Agama Budha atau Dhama (ajaran dalam Budha) berusaha meyakinkan orang bahwa siapa pun yang jujur pasti akan membenarkan simpulan bahwa hidup ini menderita, kecuali mereka yang telah mengalami pencerahan. Peace atau DS itu hanya dialami oleh mereka yang telah tercerahkan. Brahm (1915: 273) menyatakan bahwa "Budhism is all about enlightenment not just about living a healthy life, or learning to be wise and saying smart things to your friends a round the coffe table". Mereka yang mengalami pencerahan ini adalah mereka yang sungguh memahami bahwa dunia ini tidak kekal ( impermanent ) oleh karenanya mereka yang berkeinginan akan hal-hal yang duniawi ini pasti akan kecewa dan ujung-ujungnya menderita. Padahal, manusia menurut kodrat alaminya; sebelum mengalami pencerahan, akan berkeinginan tadi dan, padahal, keinginan tersebut akan terus berlanjut dan tak terpuaskan: ingin kaya, ingin terkenal, ingin berkuasa, dan ingin berlimpah dalam soal sex ( Bandingkan Hanh, 2015: 6-7 ).

Kunci kebahagiaan atau DS, dengan demikian, adalah melepaskan diri dari segala macam bentuk ikatan oleh dunia yang tampaknya menjanjikan dan penuh jerat ini. "Ya, ketika nanti saya kaya, tenar, berkuasa, dst, dst.", kata mereka yang belum mengalami pencerahan. Tidak melekat kepada apa pun yang ada di dunia ini yang secara otomatis akan membuahkan hati yang mencintai bahkan berbelas kasih kepada semua mahluk itu adalah kebahagiaan atau DS itu sendiri. Dengan gaya bertutur yang indah sekali, Brahm (hal. 298 ) menulis, "When you learn to be perfectly still, without desire in the world, and heart filled with unconditional love, only then the mangoes of enlightenment fall softly into your hand ". Lalu, lebih lanjut guru Brahm ini juga berkata bahwa, "Letting go is the enjoyment that is caused by ending things. It is the happiness of peace. .. that what we really know as true happiness, true contentment, and must be peacefulness". Demikianlah makna spesifik DS dalam subbudaya budaya /bahasa Indonesia komunitas Budhis. 
Bahagia dalam istilah yang digunakan dalam Budha bisa diartikan secara duniawi atau pun secara spiritual. Dan kedua jenis kebahagiaan itu pada dasarnya berlawanan sepenuhnya. Kebahagiaan duniawi atau kedagingan itu misalnya nonton film, nonton pertandingan sepak bola, makan enak, tamasya ke sana ke sini atau menyibukkan diri untuk mengumpulkan harta demi terkumpulnya harta itu sendiri tanpa ada ujung. Bawah sadar oranglah yang mengendalikan dan menuntun ke arah menjadi kaya, menjadi berkuasa, menjadi tenar, dan puas karena makanan serta sex. Bahagia jenis spiritual yang disebut sebagai kebahagiaan sejati dan yang sungguh-sungguh merupakan sinonim DS adalah kebalikan itu semua: kebahagiaan dalam keheningan, kesunyian, dan kestabilan. DS di sini mines loba (keserakahan), dvesa ( kebencian, kemarahan), dan moha ( kebodohan atau ketidaktahuan perihal dunia yang impermanent ).

Damai sejahtera atau bahagia spiritual dalam Budha mirip sekali dengan DS dalam kekristenan. Damai sejahtera dalam konteks Injil Yohanes pasal 14 ayat 27 yang telah dikutip di atas adalah DS yang mines kekhawatiran dan ketakutan terhadap apa pun yang bisa terjadi di dalam hidup ini. DS semacam ini hanya bisa diperoleh oleh orang yang percaya bahwa Allah Bapa itu mengasihi dunia ini (Baca manusia) dengan mengutus Firman-Nya ke dunia lewat cara menjadi manusia (Isa Almasih) dan rela berkorban karena imannya akan hidup kekal dalam dunia kekal yakni Kerajaan Allah yang dijanjikan Allah Bapa. Orang percaya yang diselamatkan adalah orang percaya yang memiliki hidup mirip dengan hidup Isa Almasih artinya rela berkorban demi kebahagiaan bahkan keselamatan orang lain. Orang yang sungguhsungguh menyadari hal tersebut dan berjuang seumur hidupnya untuk mengaplikasikannya. Di dunia ini mereka akan mengalami DS atau hidup dalam Kerajaan Allah di dunia yang sekarang ini. Kayakinan ini akan membuat orang sungguh-sungguh meyakini bahwa suka atau pun dukacita yang silih berganti menghampiri hidup manusia itu sudah tidak ada artinya. Mereka itu bagaikan umat Israel yang telah dikeluarkan dari Mesir (hidup masa lalunya) dan telah melalui hidup di Padang Gurun dan lalu berhasil masuk dan tinggal di Kanaan --Negeri Damai Sejahtera itu.

Demikianlah, setiap saat kata Syalom yang mengandung pengertian DS dalam bahasa Indonesia itu diucapkan orang, itu adalah DS dalam pengertian spesifik yang bahkan kebanyakan orang Kristen pun sedikit saja yang menyadarinya. Murid Yesus Kristus, yakni orang Kristen sejati, hidupnya akan ditandai oleh cinta kasih dan belas kasihan demi kemulyaan Allah Bapa, selalu merasa berkecukupan, selalu memaafkan, dan selalu berlindung di bawah kemulyaan, kuasa, dan Pemerintahan Allah Bapa. Orang-orang demikian adalah orang-orang yang mengalami DS dalam hidupnya.

Demikianlah konsep damai sejahtera dengan konotasi jasmaniah atau pun rohaniahnya. Sementara itu yang secara rohaniah pun masih bisa dibedakan sesuai dengan sosiolek keagamaan yang ada di dalam masyarakat berbahasa Indonesia.

\section{Penutup}


Dalam KBBI terdapat kata damai dan kata sejahtera, akan tetapi tidak terdapat bentuk atau ekspresi damai sejahtara. Hal tersebut membuktikan bahwa DS bukanlah kata majemuk melainkan sebuah frasa. DS rupanya merupakan bentuk pendek dari damai (dan) sejahtera. Halnya rupanya tidak berbeda dengan padanannya dalam bahasa Jawa yakni tentrem rahayu, setidaknya dalam Kitab Injil Yokanan ( bahasa Jawa ) pasal 14, ayat 27. DS yang sebenarnya merupakan konsep yang lebih sering digunakan di kalangan orang Kristen itu berpadanan dengan kata bahagia dalam artian yang spesifik juga dalam agama Budha maupun Islam.

Sebagai ekspresi yang memuat konsep yang nota bene berasal dari tradisi budaya kekristenan kuna itu, DS ada kalanya digantikan oleh kata sejahtera saja atau selamet atau salam sejahtera atau salam/syalom saja, akan tetapi sepertinya tidak pernah digantikan oleh kata *damai saja.

Secara umum konsep DS yang bersentuhan dengan wilayah keduniaan dan kesurgawian itu setidaknya bisa dirasakan oleh penutur bahasa Indonesia pada umumnya sedangkan makna spesifiknya, tentu saja, yang di sini bisa dikatakan sebagai makna konotatifnya cenderung dipahami secara berbeda oleh masing-masing pemeluk agama yang ada. Bagaimanapun juga, baik makna konseptulnya maupun makna konotatifnya (Lihat Leech, 1974) merupakan kekayaan perbendaharaan kemaknaan budaya/bahasa Indonesia.

\section{Daftar Pustaka}

Alkitab, Dalam Bahasa Indonesia Sehari-hari. Jakarta: Lembaga Alkitab Indonesia.

Alkitab, Terjemahan Baru. 2008. Jakarta: Lembaga Alkitab Indonesia.

Brhm, Ajahn. 20015. All Best, Hello Happiness. Jakarta: Awareness Publication.

Dardjowidjojo, Soenjono. 1987. Linguistik: Teori dan Terapan. Jakarta: Unika Adma Jaya.

Duranti, Alessandro. 1997. Linguistic Antropology. New York: Cambridge University Press.

Fiske, John. 1982. Introduction to Communication Studies. USA: Mathuen \& Co.

Hanh, Thich Nhat. 2016. The Sutra on The Eight Realizations of The Great Beings. WWW.

Mindful.Org. (diunduh Januari 2016).

Holy Bible, New International Version. 2008. Jakarta: Lembaga Alkitab Indonesia.

Holmes, Janet. 2001. An Introduction to Sociolinguistics. UK: Longman Group.

Kitab Suci. 1997. Jakarta: Lembaga Alkitab Indonesia.

Klinkert (Penerjemah). 1934. Wasijat jang Baroe, Atawa Injil Toehan Kita Jesoes Kristoes.

Amsterdam: Nederlandsch Bejbelgenootschap. 
Leech, Geoffrey. 1974. Semantics. Diterjemahkan oleh Paina P. 1974. Semantik. Surakarta Penerbit UNS.

Oetomo, Dede. 1987. “ Linguistik dan Sosiolinguistik: Dua Ancangan Terhadap Bahasa Manusia"

Dimuat dalam Dardjowidjojo.

Sugono, Dendy (red.). 2011. Kamus Besar Bahasa Indonesia. Jakarta: PT Gramedia.

Zoest, Aart van. 1993. Semiotika, Jakarta: Yayasan Sumber Agung. 